\title{
Intermediation for Technology Diffusion and User Innovation in a Developing Rural Economy: A Social Learning Perspective
}

\author{
Nicholas Theodorakopoulos \\ Aston Business School, Aston University, Aston Triangle, Birmingham B4 7ET, UK \\ David Bennett \\ Department of Technology Management and Economics, Chalmers University of \\ Technology, Gothenburg, Sweden and University of South Australia Business School, \\ Adelaide, Australia \\ Deycy Janeth Sánchez Preciado \\ Production and Innovation Regional Centre, University of Cauca, Carrera $7 \mathrm{~N}^{\circ}$ 4-36 \\ Tercer piso, Edificio Cámara de Comercio del Cauca, Popayán, Colombia
}

\begin{abstract}
Technology intermediaries are seen as potent vehicles for addressing perennial problems in transferring technology from university to industry in developed and developing countries. This paper examines what constitutes effective user-end intermediation in a low technology, developing economy context, which is an under-researched topic. The social learning in technological innovation (SLTI) framework is extended using situated learning theory in a longitudinal instrumental case study of an exemplar technology intermediation programme. The paper documents the role that academic-related research and advisory centres can play as intermediaries in brokering, facilitating and configuring technology, against the backdrop of a group of small-scale pisciculture businesses in a rural area of Colombia. In doing so, it demonstrates how technology intermediation activities can be optimised in the domestication and innofusion of technology amongst end-users. The design components featured in this instrumental case of intermediation can inform policy making and practice relating to technology transfer from university to rural industry. Future research on this subject should consider the intermediation components put forward, as well as the impact of such
\end{abstract}


interventions, in different countries and industrial sectors. Such research would allow for theoretical replication and help improve technology domestication and innofusion in different contexts, especially in less developed countries.

Keywords - university-to-industry intermediation, regional development, technology transfer, innofusion, situated learning, rural industry.

\section{Introduction}

Regional development policy in Latin America has been geared toward creating national systems of innovation, which among other priorities are expected to spur entrepreneurial development and innovatory activity within rural, agri-food sectors. In this respect, technology development and diffusion with straightforward adoption or adaptation (i.e. adoption of technology with modifications), along with enhancement of supply and demand-side human capital in these sectors, is regarded as crucial (Alcorta and Peres 1998; Etzkowitz and Brisolla 1999; Cimoli, Ferraz and Primi 2005; Beddington and Farrington 2007; Saad and Zawdie 2011). Yet, these national innovation systems appear to have evolved into weak entities, with human capital remaining low and science and technology institutions, especially universities, not fully performing an enabling role (Bebbington and Thiele 1993; Bastos and Cooper 2005; Beddington and Farrington 2007; Metcalfe 2010). A multitude of challenges have been identified in the literature, covering a broad geography (Bercovitz and Feldman 2006; Anderson, Daim and Lavoie 2007; Decter, Bennett and Leseure 2007; Hervas-Oliver et al. 2012; Ranga and Etzkowitz 2013). These relate to overcoming cultural/epistemic differences, defining accurately end-user needs, demonstrating the benefits of new technologies to potential end-users, providing 'knowhow' and taking advantage of government institutions and networks that facilitate dissemination and influence user acceptance. Notably, such challenges are exacerbated in Latin America due to a paucity of resources (Utterback 1975; Correa 1995; Alcorta and Peres 1998; Etzkowitz and 
Brisolla 1999; Cimoli, Ferraz and Primi 2005; Beddington and Farrington 2007; Saad and Zawdie 2011).

Specifically with regard to Latin American countries, as suggested by Aroneca and Sultz (2001), such challenges often relate to the connection between 'structurally unachieved' national systems of innovation and the 'social loneliness' of universities. Despite policy making efforts for a 'triple helix' of cooperative relations among university, government and rural industry, the links and interactions between these stakeholders remain tenuous (Kaimovitz 2002; Cimoli, Ferraz and Primi 2005; Beddington and Farrington 2007; Guerra Portocarrero 2013). Third sector think tanks and research and advisory (service provision) centres, are deemed as having the potential to play a significant role in addressing this problem, by coordinating stakeholders, enabling clustering and facilitating the technology transfer process in strategic sectors, such as agri-food industries (Vorontas 2002; Reece and Sumberg 2003; Pietrobelli and Rabellotti 2004; Beddington and Farrington 2007; Metcalfe 2010).

However, with only a few exceptions (e.g. Spithoven, Clarysse and Knochaert 2011; Hervas-Oliver et al. 2012), studies on the role of such intermediaries have, by and large, focused on firms operating in high technology clusters. Relatively little attention has been paid to how third-sector research and advisory centres, as technology intermediaries, facilitate technology transfer and user innovation in low technology, rural clusters of small-scale agribusinesses in developing countries. Notably, although various typologies of technology intermediaries have been developed (Bessant and Rush 1995; Howells 2006; Spithoven, Clarysse and Knochaert 2011), the modus operandi of such organisations is still not well understood. Given the strategic importance of the agribusiness/traditional sectors to the socio-economic development of many less-industrialised countries, this constitutes a significant gap in knowledge. This is even more pronounced in moderately developing Latin American economies, such as Colombia, which tend to be more resistant to the transfer of best practices and rely disproportionably on traditional/rural industrial sectors characterised by low-technology use (Pietrobelli and Barreta, 2010). 
To address the research gap described above, the driving research question is 'How do third-sector research and advisory centres, as technology intermediaries, facilitate technology transfer and user innovation in low technology rural clusters of small-scale agribusinesses in developing countries?' To tackle this question and cast light on the modus operandi of such organisations, Stewart and Hyysalo's (2008) social learning in technological innovation (SLTI) framework is extended by using situated learning theory (Lave and Wenger 1989; Brown and Duguid 1991, 1998, 2001; Wenger 1998, 2000; Swan, Scarbrough and Robertson 2002) to create a potent analytical lens. The focus here is on the mechanism of a certain type of technology intermediation programmes, i.e. run by academic-related/third sector research and advisory centres, within a low technology/traditional industry sector in a developing economy setting. The level of analysis is a successful intervention programme undertaken by a regional thirdsector intermediary, bringing together academic, local government and pisciculture industry stakeholders. This particular programme was designed to address the lack of technology transfer to small pisciculture agribusinesses, which is deemed as an issue of strategic priority in Colombia, given the importance attached to the expansion of key rural industries (Cruz-Casalias, Medina-Robles and Velasco-Santamaria 2011).

The paper is organised as follows. The second section delineates the theoretical background, explicating the constituent elements of situated learning theory used to extend Stewart and Hyysalo's (2008) SLTI framework and discusses how this perspective can help illuminate the different technology-intermediation roles in this context. Following from this, the third section outlines the research approach. The fourth section then frames the discussion of findings around the three key functions suggested by the SLTI framework, i.e. brokering, facilitating and configuring, using situated learning theory to cast light on these components of intermediation. The final section presents the conclusions of the study and suggests avenues for further research.

\section{Theoretical background}

\subsection{Research and advisory centres as intermediaries in technology transfer}


Globalisation impacts a wide range of industrial sectors, including agribusiness. RequierDesjardins, Boucher and Cerdan (2003) point out that one of the reasons for the favourable trade balances of major Latin American is their soaring exports of food products. Thus, agri-food industries constitute sectors of strategic importance in these economies, including Colombia (Torres et al. 2004). Cluster support policies targeting these sectors are based on the premise that upgrading in natural resource-based clusters should be fostered by technology improvements and diffusion of best practice in technology adoption and innovative adaptation. These underpin the adoption of quality and environmental standards and certification processes, which create common assets for the actors involved and enable access to global agri-food commodity chains, with promising opportunities (Correa 1995; Requier-Desjardins, Boucher and Cerdan 2003; Van Dijk and Sverisson 2003; Pietrobelli and Rabellotti 2004; Bastos and Cooper 2005; Cimoli, Ferraz and Primi 2005; Cruz-Casalias, Medina-Robles and Velasco-Santamaria 2011).

To this end, regional development policy in most Latin American countries, as in many developing economies, has been geared towards promoting stakeholder collaboration in research and dissemination of technology, improving the skills and abilities of existing small-scale producers, and facilitating the entry of new ones, in local production systems (RequierDesjardins, Boucher and Cerdan 2003). Importantly, such efforts aim at promoting linkages amongst propagators of technology and agri-food entities for technology adoption or innovative adaptation, at a collective/local production system level. However, universities are not adequately equipped to meet challenges related to transferring the technology demanded by Latin American agri-food systems. Two critical challenges facing universities and governments in the region are weak institutional interface structures and lack of stable funding for agricultural and natural resource management research (Kaimovitz 2002; Reece and Sumberg 2003; Cimoli, Ferraz and Primi 2005; Beddington and Farrington 2007; Saad and Zawdie 2011).

It has been suggested that third sector intermediary organisations, such as applied research and advisory centres, can mediate between other interface structures, i.e. universities, regional government agencies and co-located agribusinesses, and play an important role in the 
success of such policy initiatives (Vorontas 2002; Pietrobelli and Rabellotti 2004; Beddington and Farrington 2007; Metcalfe 2010). Successful strategies involve devoting significant resources for defining issues and market needs, providing for interpersonal contact and communication, building trust amongst stakeholders and developing the technology recipients' human capital to enhance regional production systems. There is also a burgeoning literature concerning intermediaries that help circumvent challenges pertaining to technology diffusion and innovative adoption amongst co-located end-users (Bessant and Rush 1995; Russell and Williams 2002; Williams, Slack and Stewart 2005; Steward and Hyysalo 2008; Hervas-Oliver and Albors-Garrigos 2007; Hervas-Oliver et al. 2012). Yet, this literature concerns mostly 'new economy' industries in developed countries and does not provide a sufficient understanding of what constitutes effective intermediation of this kind. This dearth of knowledge is even more conspicuous when considering research and advisory centres operating as low-technology intermediaries in rural clusters of developing countries. The following two sections delineate the analytical lens used to examine what successful technology intermediation entails in the latter case.

\subsection{Social learning in technological innovation}

Considering a host of intermediation arrangements, Steward and Hyysalo (2008) put forward the social learning in technological innovation (SLTI) framework, which maps out different types of intermediaries. They emphasise how the presence of intermediaries is in itself a key part of the overall sociotechnical innovation process and user involvement. Their SLTI framework brings into focus the concepts of domestication and innofusion between users. Domestication relates to selection, deployment and straightforward adoption or adaptation of new technology, while the notion of innofusion highlights the technological innovation occurring in these processes and underscores that key innovation episodes are taking place in the user environment. According to Steward and Hyysalo (2008), intermediaries, such as research and advisory centres, enable domestication and innofusion amongst users (adopters/adapters) of technology by undertaking three key activities: brokering, facilitating, and configuring. These functions are emphasised for their significance in fostering domestication and innofusion amongst users. 
In essence, in the SLTI framework brokering refers to raising support for the technology appropriation process from sponsors and propagators. Some of the brokering activities are related to features and functionalities of new technologies and the communication of needs and requirements of users and conditions of applications to the supply side. Facilitating relates to providing opportunities to end-users for adoption of technology by educating them, distributing resources and setting local rules. It involves creating spaces such as social communities, and networks for transferring know-how. The third function, configuring, refers to arranging and morphing the content of technology, settings rules on use, prioritising uses for production, and shaping the goals and expectations of stakeholders (for a comprehensive treatment see Stewart and Hyysalo 2008).

Steward and Hyysalo's (2008) work is significant by going some way towards illuminating the roles that technology intermediaries can play within the functions and activities identified in relevant typologies (e.g. Bessant and Rush 1995; Howells 2006; Spithoven, Clarysse and Knochaert 2011). It enhances our understanding of the dynamics through which intermediaries affect technology transfer and user innovation in different settings within a constellation of actors with different capabilities. It should be noted that Steward and Hyysalo $(2008,302)$ point out that "Even with comparatively stable technologies and use situations there can still be innovation by users..." and highlight that “...many activities and situations that are not conveniently included in the definition of innovation, are in fact important moments in innovation cycles". Yet, their treatment is primarily centred on Information and Communication Technology (ICT) innovation - i.e. not on low level technology innovation, mirroring a general tendency and significant omission in the intermediation literature (Spithoven, Clarysse and Knochaert 2011).

Moreover, although Stewart and Hyysalo's (2008) approach to end-user intermediation is one of social learning, purportedly drawing on a range of research fields, it is not grounded - at least not explicitly - on a social learning theory. Arguably, this aspect of their framework 
relating to domestication and innofusion in industries of low technology can be refined in the rural industries of developing economies, by using situated learning theory as an extension lens.

\subsection{Situated Learning Theory}

Situated learning theory has gained momentum recently, providing an alternative to conventional approaches to diffusing knowledge, learning and innovating. The notion of 'Community of practice' $(\mathrm{CoP})$ constitutes its central construct, defined as “....a group of people who share a concern, a set of problems, or a passion about a topic, and who deepen their knowledge and expertise in this area by interacting on an on-going basis" (Wenger, McDermott and Snyder 2002 , 4). Its primary tenet is that knowledge diffusion and learning is fundamentally a social phenomenon, reflecting the social nature of human beings with knowledge capability and it is understood as the development of a new identity, based on participation in CoPs. For Wenger, the construct 'community of practice' constitutes a point of entry into a broader conceptual framework, which underscores the importance of community, practice, learning, meaning and identity as elements that '... are deeply interconnected and mutually defining' (Wenger 1998, 5). These components illuminate the learning process - in this case, learning to diffuse or absorb a new technology - pointing out what matters about transferring knowledge and placing emphasis on its tacit component. Notably, situated learning theory has been employed previously to better understand strategic learning and development in small firms (Jones, Macpherson and Thorpe 2010) as well as supply chain learning initiatives as vehicles for enhancing entrepreneurship and regional development, involving large procurers and small suppliers (Theodorakopoulos, Ram and Beckinsale 2013).

According to situated learning theorists (Brown and Duguid 1998, 2001; Wenger 1998, 2000; Swan, Scarbrough and Robertson 2002; Snyder and Wenger 2010; Theodorakopoulos, Ram and Beckinsale 2013) the ability of a CoP to create new meanings about what matters in pursuing an enterprise or to learn new competencies (such as in this case optimising diffusion and adoption, or adaptation of pisciculture technology) depends on three factors. First, the strength of the community; second, the quality of its 'boundaries' (the spaces where different 
CoPs interface) and third, the health of the communal identity that enables the creation of new meaning and learning. The strength of a CoP refers to how well its members engage and participate socially in the community's efforts towards the achievement of a common purpose. It also relates to how well a $\mathrm{CoP}$ can coordinate perspectives, interpretations and actions so that higher goals are realised. Promoting connectivity, active membership and artefacts such as symbols, documents and tools enhance the strength of a CoP. The quality of the boundaries within which different CoPs socially interact is determined by the establishment of 'brokers' (i.e. mediators with an understanding of the interacting CoPs), the presence of common 'boundary objects' (e.g. agendas, action plans, assessment frameworks and technologies in use) and the potency of boundary encounters (i.e. how well these events allow for meaningful interaction among interfacing CoPs). Healthy identities are characterised by connectedness (i.e. uniting members), expansiveness (i.e. allowing space for new perspectives) and effectiveness (i.e. enabling participation and action). Hence, taking a situated learning theory perspective in extending Steward and Hyysalo's (2008) three main functions of end-user intermediaries concerned with domestication and innofusion (brokering, facilitating and configuring) places emphasis on the design elements of CoPs discussed above, i.e. brokerage, boundary interactions, boundary objects and development of identities and meanings.

Examining the functions of third sector research and advisory centres as low technology intermediaries in rural industries of less developed Latin American countries, such as Colombia, is warranted on two counts. First, such research and advisory centres constitute key elements of their regional development policy (Pietrobelli and Rabellotti 2004; Cimoli, Ferraz and Primi 2005; Pietrobelli and Barreta 2010), and second it offers the opportunity to examine how lowtechnology intermediation functions can differ across markedly different institutional arrangements and clustering contingencies (Requier-Desjardins, Boucher and Cerdan 2003; Hervas-Oliver 2012). Therefore, this study considers the role that third sector research and advisory centres can play as intermediaries in brokering, facilitating and configuring lowtechnology for adoption or adaptation, against the backdrop of rural industry in Colombia. The following section deals with the methodology of this study. 


\section{Research Context and Design}

The Production and Innovation Regional Centre (abbreviated here as PIRC) is an academicrelated research and advisory centre in the Cauca region of Colombia. As an end-user technology intermediary, it is positioned between a regional university and co-located pisciculture businesses operating in Silvia, a prefecture of Cauca region. PIRC created a coalition comprising the Centre itself, the regional University, two regional Government Agencies, the Chamber of Commerce and a local trade association representing producers. This coalition was concerned broadly with enhancing technology diffusion and innovatory activity in regional industries. One of the most successful intervention programmes devised by the coalition, targeted a local production system of 44 small-scale pisciculture businesses. The programme was delivered over a period of two years and the majority of technology recipients were micro enterprises (employing fewer than 10 workers), with size being subject to seasonal variation.

This intermediation initiative led to an improvement in measurable outcomes and is regarded as successful by the stakeholders involved, facilitating the transition of the pisciculture system from 'local market' cluster to more advanced stages (Bolaños and Ledezma 2014), which exhibit features of the 'innovative' and 'industrial district' types of interdependence (Van Dijk and Sverrisson 2003). Notably, the pisciculture industry is considered significant for regional development (Sánchez, Plazas and Pemberthy 2008; Cruz-Casalias, Medina-Robles and VelascoSantamaria 2011) and the diffusion of the technologies in question among co-located fish farmers aimed at improving their cost savings, productivity, quality of produce and access to multinational corporation (MNC) supply chains through certification. These technologies are novel and eco-friendly, addressing innovativeness and environmental considerations, which are rated highly in the regional agenda of economic development and sustainability.

Table 1 illustrates the types of technology transferred and the extent of adoption by participant fish farmers, as a result of this programme. 
Insert Table 1 here

The technologies were transferred in packages, entailing soft and hard components, which were often adapted according to the needs of each pisciculture enterprise. Innovative adaptation that occurred in a given establishment was diffused across the network. This was achieved by providing participants with the necessary level of competence to engage in technology adoption and innovative adaptation in their cluster (Hervas-Oliver et al. 2012). The majority of pisciculture businesses adopted combinations of different operational technologies that are usually applied concurrently. The types of technology not adopted by certain participants were those considered unsuitable for their individual circumstances. Arguably, the diffused technologies improved significantly the competitive performance of the participant pisciculture businesses. The vast majority of the recipients of technology reported significant increases in productivity (exceeding $200 \%$ in some cases), as well as cost savings and considerable quality improvement against the main customer standards. Applying these new technologies collectively enabled them to develop coordination capabilities and capture rents at collective level (Bolaños and Ledezma 2014), which can contribute to generating regional advantage (Gellynck, Vermeire and Viaene 2007). Being integrated within a local network offering high quality products enabled participant pisciculture businesses to create common assets and reach international markets that offer better prices and profit margins. As a result, profits for many fish farmers exceeded $250 \%$.

Given its success in developing a coalition with local stakeholders and transferring valuable technology to participant pisciculture businesses, with significant outcomes, PIRC's intermediation programme is selected as an instrumental or demonstration case (Stake 1994; Yin 2003) in this study. Regarding this intervention, arguably, the academics, the members of the two regional Government agencies, the regional Chamber of Commerce and PIRC, all belong to different networks of practice or 'epistemic cultures' (Brown and Duguid 1998). As such, they represent different competencies, views, repertoires and priorities regarding technology diffusion in the region. Conversely, local pisciculture businesses constitute a distinct network of practice, 
or conceivably a CoP (Theodorakopoulos et al. 2013; Swan, Scarbrough and Robertson 2002). Although the severity of the challenges they face may vary, being largely dependent on the age and stage of development of the business, at a broad level each of these groups is concerned with a particular type of enterprise. To a certain extent, the aforementioned challenges entailed in university-industry technology transfer are explained by the fact that supply-side stakeholders concerned with technology diffusion and pisciculture businesses as technology recipients represent different CoPs (Sanchez-Preciado 2010). This brings to centre-stage the potential for technology intermediation initiatives that manage to bridge such 'epistemic gaps' between supplier and user CoPs by brokering, facilitating and configuring. Therefore, this intervention as an instrumental case is revelatory of the role that an intermediary of this kind could play concerning domestication and innofusion within traditional/low technology industries in resource-challenged local production systems and is suitable for applying the extended theoretical lens delineated in the previous section.

With PIRC's intervention as the unit of analysis, a longitudinal 'engaged scholarship' approach was adopted; that is, a "participative form of research for obtaining the perspectives of key stakeholders to understand a complex social problem" (Van de Ven 2007, 10). Data on the programme's brokering, facilitating and configuring functions were drawn from multiple sources, including PIRC staff acting as consultants in this initiative, pisciculture business owners and key informants of the regional government agencies involved in the initiative. These data were collected through participant and non-participant observation of the programme functions, as well as through personal interviews with various stakeholders involved, including PIRC consultants, participating officials and business owner-managers. To this end, the log books and feedback sheets that were used during steering group meetings (six occasions), workshops (six occasions) and follow up visits throughout the programme (exceeding 200 occasions in total) were scrutinised. Examination of records containing agendas, strategic and tactical plans and the types of adopted pisciculture technology supplemented the main methods of data collection. These enabled an understanding of the participants' views on the intermediation functions and the domestication and innofusion processes that took place during the intervention. 
Analysis of data relating to brokering, facilitating and configuring pisciculture technology in the processes of domestication and innofusion was guided by situated learning theory (Brown and Duguid 1998, 2001; Wenger 1998, 2000; Handley, Sturdy, Fincham and Clark 2006; Theodorakopoulos, Ram and Beckinsale 2013). This helped the researchers create initial categories and be explicit about their assumptions and values, heeding Johnson, Duberley, Close and Cassel's (1999) call for situational and epistemic reflexivity. Triangulation of sources was also achieved by considering the accounts of the different stakeholders involved in this intervention. The general analytic procedure suggested by Miles and Huberman (1994) was used in the sorting, analysis and presentation of data. The coding procedure was discussed among three researchers to increase the rigour of the analytical generalisation of empirical data (Yin 2003; Moriceau 2009). Overall, every effort was made to provide an 'audit trail', maintaining a database documenting data collection and analysis procedures (Yin 2003).

\section{Using Situated Learning Theory to Understand the three Intermediation Functions}

\subsection{Brokering as building a coalition Community of Practice}

In this case, forming learning networks to enable collective capacity building and process innovation amongst different participant stakeholders concerned with technology diffusion highlights the significance of neutral external intermediaries as brokers that mediate cooperation and draw together disparate interests (Vorontas 2002; Pietrobelli and Rabellotti 2004; Beddington and Farrington 2007). A CoP perspective can further elucidate the role that intermediaries of this kind can play as integrating institutions (Garrety, Robertson and Badham 2004; Metcalfe 2010). Over the two-year period of this intermediation programme, PIRC brought together researchers/consultants, government officials from two regional Government Agencies, University of Cauca and the regional Chamber of Commerce, as well as a trade association linking pisciculture businesses into a network of producers. This represented a coalition CoP or a 'boundary' CoP (Wenger 2000; Brown and Duguid 2001; Swan, Scarbrough and Robertson 2002). 
For 'brokers', 'generative boundary interactions' constitute instrumental elements of a social strategy for promoting the learning of CoPs interacting at 'boundaries' (Brown and Duguid 1998, 2001; Wenger 1998, 2000; Snyder and Wenger 2010). A forum, or 'boundary space', of paramount significance for the coalition CoP was the meetings of the steering group, where strategic and tactical plans concerning the types of pisciculture technology and modes of transfer were formulated. Notably, the creation of the steering group in itself, and its membership structure, presented considerable challenges. CoPs of this nature are beset by ambiguity, complexity and dynamism that present enormous challenges to the practitioners who nurture them (Huxham and Vangen 2000). Working with entities that have to some extent their own agendas, use different professional languages, and operate within different organisational structures and paradigms, as well as managing power relationships and accountabilities in securing commitment and agreeing goals, proved far from easy. In the words of the architects of the intervention:

'You see different groups of people, or professional groups, see things differently because their understanding, priorities and needs with regard to a given technology are different; because their understanding and needs exist at different levels. For example, government officials understand technology as progress, which will boost productivity, development, environmentalism; and so the more it's used, the better...' (PIRC team member, P1)

'High adoption and impact in this programme, make it an example of best practice, which is used to persuade other regions to use the technology. The fish farmer is not so much interested in this. For them the pressing need is to adapt technology in a way that works; increasing their margins, cutting their costs, giving them access to procurement systems.' (PIRC team member, P3)

Moreover, determining the agenda of the steering group was a delicate consultation process and instrumental in securing commitment. PIRC, as a broker and coordinator of this coalition CoP, pushed immediately for a common agenda and a set of goals. The agenda, goals, action plans and technology diffusion assessment frameworks served as common artefacts or 'effective boundary objects' for the members of the coalition who represented different CoPs (Brown and Duguid 1998, 2001; Wenger 1998, 2000). Put another way, these artefacts as boundary objects mediated learning amongst participants (Jones, Macpherson and Thorpe 2010). They enabled them to negotiate their relationships, connect their perspectives and develop a common, expansive and effective identity in situated learning theory terms. They helped 
establish converging institutional logics among participants of relatively equal status, aligning their interests and setting objectives and priorities that were meaningful to them (Garrety, Robertson and Badham 2004; Bjerregaard 2010), through a process of institutional thickening (Veluzzi 2010). The view expressed by one of the intermediary members is illustrative:

'I think one of the key success factors of programmes of this nature is selecting carefully the members of the steering group, i.e. influencing as much as possible the dynamics of the group. You need right mix of people. People with expertise, of similar status and suitable ethos. You don't want people with huge egos or those who dominate discussions or promise a lot but do very little...You certainly need to streamline activities by expediting the setting of an agenda and a plan that everyone relates to, so that they are glued together...to build and maintain momentum... and then agree on how progress will be monitored and assessed - that's again very important'. (PIRC team member, P2)

In the light of the above, the following two propositions are put forward:

P1: Brokering, as an intermediation function, involves building a balanced membership structure of a coalition of stakeholders concerned with technology diffusion to rural industry. This is essential for fostering identification, avoiding harmful power relations and building a strong community of practice, where stakeholders can develop the identities and competences required for technology diffusion to rural industry.

P2: Brokering, as an intermediation function, involves the pursuit of a clear agenda, wellinformed action plans, agreed assessment frameworks and technologies in a coalition of stakeholders. This is essential for building a strong community of practice, within which the stakeholders concerned with technology diffusion to rural industry can develop supportive identities and required competences.

Members of the coalition convened in six steering group meetings during the two yearprogramme. They contributed to designing the format of the six workshops that PIRC delivered to fish farmers so that the latter had the opportunity to familiarise themselves with new pisciculture technologies and learn about their management and support available. The next section deals with the workshops and follow-up visits to participating fish farmers. These, in conjunction with each other, constitute the second key component of the technology transfer programme, and relate to the facilitating and configuring roles of the intermediary. 


\subsection{Facilitating and configuring via workshops and training/technical assistance visits}

In less advanced new technology situations, an appropriate approach to integrating such technology would be to seek out those resources that can help to understand it (Karlsson, Johansson and Stough 2010). In that respect, a number of studies in CoPs have highlighted the importance of brokers as facilitators (Wenger 2000; Handley, Sturdy, Fincham and Clark 2006; Theodorakopoulos, Ram and Beckinsale 2013). With regard to pisciculture businesses as technology recipients, throughout the duration of the programme, PIRC as a facilitator of technology transfer and innovative adaptation delivered six workshops to 44 fish farmers. The latter group comprise a network of co-located pisciculture businesses connected to a central node, a local fish trade association with the acronym APROPESCA. PIRC helped with configuring the domestication of technology in the local production system of these pisciculture businesses by selecting the technologies most likely to be adopted. Later, when different types of technology had been applied and adapted by the users in innovative ways, they helped to configure the process of innofusion. As Stewart and Hyysalo (2008) put it, these processes are not just technical but also symbolic, involving what Wenger $(1998,2000)$ calls reification of meaning. Being embedded in the local production system, PIRC provided an interpretation of the technology, the meanings that government officials and users give to the programme, and then adjusted the programme to reflect such interpretations.

New technologies were showcased, explaining their application and benefits to participating fish farmers. These events were followed by visits of PIRC team members to the participant pisciculture businesses for providing one-to-one assistance with adopting and configuring these technologies. The six workshops and follow-up visits (on average five visits to each participant pisciculture business) can be viewed as significant boundary events for the CoPs involved (Brown and Duguid 1998, 2001; Wenger 1998, 2000) - in this case being members of the coalition/PIRC and fish farmers. As mentioned earlier, according to situated learning theory, the quality of boundaries as spaces of interaction between different CoPs is influenced by the presence of specific factors that can inhibit or enhance engagement and alignment of interfacing CoPs. In these events, advisors who represent the coalition, put forward boundary objects 
(Brown and Duguid 1998, 2001; Wenger 1998, 2000) such as the technologies on offer, explicating unambiguously to participant fish farmers how these types of technology can benefit their businesses within the context of regional development planning. This clarity of boundary objects has been found to be a critical success factor in developmental initiatives of a similar nature (Theodorakopoulos, Ram and Beckinsale 2013). Moreover, importantly, these events strengthened these two CoPs by providing a forum where their members can interact socially and learn from each other about transferring, adopting and adapting the technologies in question. The quotes below are illustrative:

'As to the workshops and the assistance visits, I think they were very useful not only for showing what can be achieved with different technologies but also because we got the chance to talk to users and see what they are thinking about these technologies and how they apply them. I think that was very important for building trust and finding out what their needs are, what the problems or difficulties could be with technology adoption and how to deal with them, how to adopt technology innovatively in a way that suits their needs...doing this collectively brings about a collective mindset for all involved'. (Programme Expert 2)

'In the workshops we got to see what technology is on offer and what the gains are...what was good was that this was presented very clearly...Then during the visits we got some help with dealing with any problems and adjusting the technology. But what we learn from each other is also very important. You are not alone, you have the opportunity to start something together and then knowing that you have someone to turn to for advice, share about the technology, makes you willing to try it... and this could be the advisor during the visit, but in many cases it could be a fellow farmer who works with the same technology'. (Fish Farmer F15)

Based on the above discussion the following proposition is advanced:

P3: Configuring technology and facilitating innovative adaptation at a collective level, as an intermediation activity, involves the handling of clear boundary objects (technology types), in boundary events (workshops and technical assistance visits) which clearly articulate the rationale, requirements and opportunities in technology domestication and innofusion. 
It has to be noted that institutional arrangements can play an important role in the domestication and innofusion of technology. A case in point is Luna and Tirtido's (2008) study, which highlights the contribution of business associations to knowledge networks in Mexico. The significance of business associations is echoed in the intervention this paper reports upon. Of special note is the role that APROPESCA (the local fish trade association) played in facilitating the organisation of these events, building trust, legitimising and 'translating' the technologies on offer and engaging meaningfully with participants. Under situated learning theory, through acting as a broker (Brown and Duguid 1991; Wenger 1998, 2000) in partnership with PIRC, they enabled participant pisciculture businesses owners to understand how the different types of technology on offer could serve them and how such technology fits within the wider regional agenda of productivity and innovation held by the coalition. Conversely, APROPESCA as a broker helped the coalition make these particular events more effective, by providing the perspective of its members as potential recipients and adapters of technology. In its partnership with PIRC, the association assisted in disseminating good practice in configuring and adapting pisciculture technology, as well as in setting operational standards within the local production system. In situated learning theory terms, within the pisciculture network of APROPESCA, fish farmers were able to expand their identities as innovatory technology adapters and to reap the benefits of domestication and innofusion. Instrumental was the provision of knowledge to the local pisciculture system about how the technology can be used to meet the requirements of foreign markets, orienting these agribusinesses as a collective to the international production environment (Gellynck, Vermeire and Viaene 2007). The following quotes are instructive:

'The role of PIRC and APROPESCA in diffusing innovative adaption of pisciculture technologies, standardization, and dissemination of good practice amongst participating farms was very important...To extend the practice to other pisciculture businesses, the way to do it is to acknowledge the most expert fish farmer, say one who came up with an innovatory or cost effective application of technology and extend that mode to others within the network, but in the right pace so that these businesses are comfortable with transition...'. (LG official)

'APROPESCA played an instrumental role as a broker in the propagation of innovatory adaption of technology and dissemination of good practice... because of this, fish farmers 
see themselves as adopters or better, innovatory adapters. Eventually, they are looking to replicate these practices in other regions.' (Programme Expert 1)

PIRC involved APROPESCA as an institution to help them [participants] learn to function this way, to instil this mindset of collective adoption.... Some of these solutions were actually quite innovative...They promoted process and output standards to achieve certification and reach foreign markets. These were documented so that they can be used in future projects in other places.” (Programme Expert 3)

In light of the above, the following proposition is submitted:

P4: Configuring technology and facilitating innovative adaptation, as an intermediation activity, involves the employment of other trustworthy brokers, who are embedded in the local production system. Their understanding of and credibility with the supply and demand sides enables the fine-tuning of the programme and the development of the identities and competences needed for transferring, adopting and adapting technologies effectively at a collective level.

Based on the above discussion in Sections 4.1 and 4.2, Illustration 1 summarises the key components of the programme's intermediation functions of brokering, facilitating and configuring.

\section{Insert Illustration 1 here}

Synoptically, in this conceptualisation, the components of these three intermediation functions are understood through the lens of situated learning theory. More specifically, brokering refers to establishing a coalition of stakeholders concerned with technology transfer as a balanced CoP, as well as hosting generative boundary events (steering group fora) and using effective boundary objects (agendas, plans, assessment frameworks and technologies) and brokers to align its members. Through these activities, transferors of technology can develop identities, meanings and competences that are conducive to optimising the technology diffusion process. Facilitating 
and configuring as intermediation functions relate to providing generative boundary events for recipients of technology (training events and assistance visits) and recruiting embedded, trustworthy brokers that facilitate the legitimation, translation and adoption or innovative adaptation of technology. Through these activities, recipients of technology can develop identities, meanings and competences that are conducive to collective domestication and innofusion.

\section{Conclusions and Avenues for Further Research}

The focus of this paper is on academic-related, independent research and advisory centres, which constitute a particularly significant type of technology intermediary and a key feature of regional development policy in many Latin American countries, and deals with an instrumental case of technology-diffusion intervention. The diffused technologies were adopted to address specific needs of agribusinesses, through mass-technology customisation activities, aiming at domestication and innofusion of technology. The latter refer to collective adoption of the technologies discussed, in many cases by innovative adaptation. As this case demonstrates, domestication and innofusion through brokering, facilitating and configuring of technology in the way discussed can bring about cost savings as well as substantial improvements in quality, and productivity for the local participant pisciculture businesses. This in turn is pivotal for agribusinesses in the local production system, as such improvements enable their certification, creation of common assets and access to international supply chains. These are commendable, as they have the potential to improve significantly the competitive position of the local production system.

Knowing 'what works' is regarded as instrumental for designing interventions (Pawson and Tilley 1997; Sanderson 2000; Pawson 2006). In this case, it is significant for undertaking 
future technology intermediation initiatives in a way that addresses structural interface deficiencies and promotes the enhancement and innovative activity of rural production systems. In illustrating the key components of the PIRC intervention, it is explicated how constructs posited by situated learning theorists can improve our understanding of the role that third sector/academic-related intermediaries play in the process of domestication and innofusion of technology. It is suggested that Stewart and Hyysalo's (2008) three main intermediation functions (brokering, facilitating and configuring) in technology domestication and innofusion can be improved by optimising the intervention components that were submitted as theoretical propositions, and presented summarily in Illustration 1. These refer to establishing a coalition of stakeholders concerned with technology transfer as a balanced CoP, using effective boundary objects (agendas, plans, assessment frameworks and technologies), in generative boundary spaces (steering group fora, training events and assistance visits). They also relate to recruiting embedded brokers that facilitate the legitimation, translation and adoption or innovative adaptation of the technology concerned. Through these activities, transferors and recipients of technology can develop identities, meanings and competences that are conducive to domestication and innofusion of technology.

Notably, by drawing on an instrumental, demonstration case (Stake 1994; Yin 2003) - not a sample of one - the intervention components put forward as theoretical propositions convey generic tendencies and highlight 'what could be' (Schofield 2000), extending Stuart and Hyysalo's (2008) framework. Put another way, although the exemplar initiative examined in this study deals with low-technology intermediation between a third sector/academic related institute and the pisciculture industry in a rural region of Colombia, it is not strictly delimited. It is purported that the insight gained from nurturing and bridging CoPs in undertaking universityindustry technology intermediation in this specific setting may be transferable to similar contexts involving community engagement programmes of this nature. That is to say, the key components of this intervention, submitted as theoretical propositions, merit the attention of those concerned with university-industry technology transfer, especially in the context of a developing economy. Such stakeholders include intermediation practitioners, academics and public administrators. 
Notwithstanding the value of demonstrating 'what could work' in intermediation initiatives that deliver positive outcomes in the context examined, such outcomes should eventually be linked to social and economic impacts. A limitation of this study is that it was not designed to undertake an evaluation of the impacts of the improvements reported in the local production system on the local economy, society and environment. Future research should consider measures of local economic, social and environmental performance, in order to obtain a more integrated view of the relationship between intervention outcomes and rural development at the local level (Baumgartner, Schulz and Seidl 2013). Given that prior research has indicated some adverse effects of interventions on local social capital (Phillipson, Gorton and Laschewski 2006; Atterton 2007), such an assessment should consider both positive and negative effects.

Another limitation of this study is that it is based on a single demonstration case and the findings may not be easily transferrable to other types of clusters or different countries, where different institutional arrangements may prevail (Wellbrock and Roep 2014). To strengthen theoretical development, more interventions of this nature need to be considered, in differing settings, for theoretical replication (Yin 2003; Eisenhardt and Graebner 2007). Such research would not only provide real-world laboratories for improving technology domestication and innofusion among end-users, but also cast light on the role that different contextual arrangements may play in facilitating or inhibiting university-industry intermediation. Finally, a promising avenue for future research is examining how research and advisory centres, as institutional entrepreneurs, fill institutional voids (Mair, Marti and Ventresca 2012) in order to effect domestication and innofusion, within a variety of local production systems, by using situated learning theory.

\section{References}

Alcorta, L., and W. Peres, 1998. Innovation systems and technological specialization in Latin America and Caribbean. Research Policy 26 (7-8): 857-881. 
Anderson, T.R., T.U. Daim, and F.F. Lavoie. 2007. Measuring the efficiency of university technology transfer. Technovation 27 (5): 306-318.

Aroneca, R., and J. Sultz, 2001. Changing knowledge production and Latin American Universities. Research Policy 30 (8): 1221-1234.

Atterton, J. 2007. The 'strength of weak ties': Social networking by business owners in the Highlands and Islands of Scotland. Sociologia Ruralis 47(3), 228-245.

Bastos, M.I. and Cooper, C. 2005. Politics of Technology in Latin America. London: Taylor \& Francis.

Baumgartner, D., T. Schulz, and I. Seidl. 2013 Quantifying entrepreneurship and its impact on local economic performance: A spatial assessment in rural Switzerland. Entrepreneurship and Regional Development 25 (3-4): 222-250

Bebbington, A., and G. Thiele. 1993. Non-governmental Organizations and the State in Latin America: Rethinking Roles in Sustainable Agricultural Development. New York, NY: Routledge.

Beddington, A., and J. Farrington. 2007. Governments, NGOs and agricultural development: Perspectives on changing inter-organisational relationships. Journal of Development Studies 29 (2): 199-219.

Bercovitz, J., and M. Feldman. 2006. Entrepreneurial universities and technology transfer: a conceptual framework for understanding knowledge-based economic development. Journal of Technology Transfer 31: 175-188.

Bessant, J., and H. Rush. 1995. Building bridges for innovation: the role of consultants in technology transfer, Research Policy 24: 97-114. 
Bjerregaard, T. 2010. Industry and academia in convergence: Micro-institutional dimensions of R\&D collaboration. Technovation 30 (2): 100-108.

Bolaños, S., and M. Ledezma. 2014. Contexto de la piscicultura en Colombia y el Departamento del Cauca (Context of Pisciculure in Colombia and the Department of Cauca), Centro Regional de Productividad e Innovación del Cauca, Working paper CREPIC-DT-I-201401, Popayan, Colombia: CREPIC.

Brown, J., and P. Duguid. 1991. Organisational learning and communities of practice: Towards a unified view of working, learning and innovation Organization Science 2 (1): 40-57.

Brown, S.J., and P. Duguid. 1998. Organizing knowledge. California Management Review 40 (3): $90-111$.

Brown, S.J., and P. Duguid. 2001. Knowledge and Organisation: A Social Practice Perspective. Organizational Science 12 (2): 198-213.

Cimoli, M., J.C. Ferraz, and A. Primi. 2005. Science and Technology Policies in Open Economies: The case of Latin America and the Caribbean, Santiago, Chile: United Nations.

Correa, C.M. 1995. Innovation and technology transfer in Latin America: a review of recent trends and policies. International Journal of Technology Management 10 (7-8): 815-846.

Cruz-Casalias, P., V.M. Medina-Robles, and Y.M. Velasco-Santamaria. 2011. Fish farming of native species in Colombia: Current situation and perspectives. Agriculture Research.42 (6): 823-831.

Decter, M., D. Bennett, and M. Leseure. 2007. University to business technology transfer - UK and USA comparisons. Technovation 27 (3): 145-155. 
Eisenhardt, K.M., and M.E. Graebner. 2007. Theory building from cases: Opportunities and challenges. Academy of Management Journal 50 (1): 25-32.

Etzkowitz, H., and S.N. Brisolla. 1999. Failure and success: The fate of industrial policy in Latin America and South East Asia. Research Policy 28 (4): 337-350.

Garrety, K., P.L. Robertson, and R. Badham. 2004. Integrating communities of practice in technology development projects. International Journal of Project Management 22: 351358.

Gellynck, X., B. Vermeire, and J. Viaene. 2007. Innovation in food firms: contribution of regional networks within the international business context, Entrepreneurship and Regional Development 19: 209-226.

Guerra Portocarrero, R. 2013. The Hidden Triad: A proposal of how to 'move' Latin American universities toward an ecosystem of innovation based upon studies of the state of affairs in Peru, Proceedings of Triple Helix International Conference, July 8-10, London, UK

Handley, K., A. Sturdy, R. Fincham, and T. Clark. 2006. Within and Beyond Communities of Practice: Making Sense of Learning Through Participation, Identity and Practice, Journal of Management Studies 43 (3): 641-653.

Hervas-Oliver, J.L., and J. Albors-Garrigos. 2007. Do the cluster's resources and capabilities matter? An application of the resource-based view n clusters. Entrepreneurship and Regional Development 17 (2): 293-283.

Hervas-Oliver, J.L., J. Albors-Garrigos, B. De Miguel, and A. Hidalgo. 2012. The role of absorptive capacity and the technology transfer process in clusters: How effective are technology centres in low-tech clusters? Entrepreneurship and Regional Development 24 (7-8): 523-559. 
Howells, J. 2006. Intermediation and the role of intermediaries in innovation. Research Policy 35 (5): 715-728.

Huxham, C., and S. Vangen. 2000. Ambiguity, complexity and dynamics in the membership of collaboration. Human Relations 53: 771-806.

Johnson, P., J. Duberley, P. Close, and C. Cassel. 1999. Negotiating field roles in manufacturing management research - The need for reflexivity. International Journal of Operations and Production Management 19 (2): 1234- 1253.

Jones, O., A. Macpherson, and R. Thorpe. 2010. Learning in owner-managed small firms: Mediating artefacts and strategic space. Entrepreneurship and Regional Development 22 (7-8): 649-673.

Kaimovitz, D. 2002. The role of non-governmental organizations in agricultural research and technology transfer in Latin America. World Development 21 (7): 1139-1150.

Karlsson, C., B. Johansson, and R.R. Stough. 2010. Entrepreneurship and Regional Development: Local Processes and Global Patterns. Cheltenham: Edward Elgar

Lave, J., and E. Wenger. 1989. Situated learning: Legitimate peripheral participation. Cambridge: Cambridge University Press.

Luna, M. and R. Tirtido. 2008. Business associations and their contribution to knowledge networks in Mexico. International Journal of Technology Management and Sustainable Development 7(3): 251-264.

Mair, J., I. Marti and M.J. Ventresca. 2012. Building inclusive markets in rural Bangladesh: How intermediaries work institutional voids. Academy of Management Journal 55: 819-850. 
Metcalfe, A.S. 2010. Examining the trilateral networks of the triple helix: Intermediating organizations and academy-industry-government relations. Critical Sociology 36 (4): 503-519.

Miles, B., and A.M. Huberman. 1994. Data Management and Analysis Methods, London: Sage.

Moriceau, J.-L. 2009. "Generalizability” in Encyclopedia of Case Study Research, eds. Mills, A. J., Durepos, G. and Wiebe E. Newbury Park, CA: Sage. 419-422.

Pawson, R. 2006. Evidence-Based Policy: A Realist Perspective. London, Sage Publications.

Pawson, R. and N. Tilley. 1997. Realistic Evaluation. London, Sage Publications.

Phillipson, J., M. Gorton, and L. Laschewski. 2006. Local business co-operation and the dilemmas of collective action: Rural micro-business networks in the north of England. Sociologia Ruralis 46 (1): 40-60

Pietrobelli, C., and T. Barreta. 2010. Enterprise Clusters and Industrial Districts in Colombia's Fashion Sector. European Planning Studies 10 (5): 541-562.

Pietrobelli C., and R. Rabellotti. 2004. Upgrading in Clusters and Value Chains in Latin America The Role of Policies, Sustainable Development Department, Best Practices Series, Felipe Herrera Library. Inter-American Development Bank, Washington, D C

Ranga, M., and H. Etzkowitz. 2013. Triple Helix systems: an analytical framework for innovation policy and practice in the Knowledge Society, Industry \& Higher Education 27 (3): 237-262

Reece, J.D., and J.D. Sumberg. 2003. More clients, less resources: toward a new conceptual framework for agricultural research in marginal areas. Technovation 23 (5): 409-421. 
Requier-Desjardins D., F. Boucher, and C. Cerdan. 2003. Globalisation, competitive advantages and the evolution of production systems: rural food processing and localized agri-food systems in Latin American countries, Entrepreneurship and Regional Development 15: 49-67.

Russell, S., and R. Williams. 2002. Concepts, spaces and tools for action? Exploring the policy potential of the social shaping perspective. In eds Sorensen, K., and R. Williams Shaping Technology, Guiding Policy: concepts, Spaces and Tools, 133-154. Cheltenham: Edward Elgar.

Saad, M., and G. Zawdie. 2011. Theory and Practice of Triple Helix System in Developing Countries: Issues and Challenges, Oxon: Routledge

Sánchez, D. J., A. L. Plazas, and L. S. Pemberthy. 2008. The Development of a Knowledge Map as a Contribution to the Consolidation of the Regional System of Science, Technology and Innovation in the Region of Cauca - Final Report. Popayan, Colombia: CREPIC (Centro Regional de Productividad e Innovación del Cauca).

Sanchez-Preciado, D. 2010. Comunidades de Práctica en el Cauca. Relación Universidad Empresa Estado: Una Dinámica de Participación y Construcción Colectiva en el Cauca (Relations Among University, Enterprise and State: Dynamics of Participation and Collective Construction in Cauca), pp 20-56. Universidad del Cauca, Colombia. ISBN 978-958-732-049-7.

Sanderson, I. 2000. Evaluation in complex policy systems. Evaluation 6 (4): 433-54.

Schofield, J.W. 2000. Increasing generalizability of qualitative research. In eds Gomm, R., M. Hammersley, and P. Foster., Case Study Method, 69-97. London: Sage. 
Snyder, W.M., and E. Wenger. 2010. 'Our world as a learning system: A communities of practice approach'. In ed Blackmore, C. Social Learning Systems and Communities of Practice, 201-218. Milton Keynes: Springer/Open University.

Spithoven, A., B. Clarysse, and M. Knochaert. 2011. Building absorptive capacity to organise inbound open innovation in traditional industries. Technovation 31 (1): 10-21.

Stake, R.E. 1994. Case Studies in eds Denzin, N.K., and Y.S. Lincoln, Handbook of Qualitative Research, 236-247. Thousand Oaks: Sage.

Stewart, J., and S. Hyysalo. 2008. Intermediaries, users and social learning in Technological Innovation. International Journal of Innovation Management 12 (3): 295-325.

Swan, J., H. Scarbrough, and M. Robertson. 2002. The construction of communities of practice in the management of innovation. Management Learning 33 (4): 477-496.

Theodorakopoulos, N., M. Ram, and M. Beckinsale. 2013. Developing Large Procurers and Ethnic Minority Business Owners for Supplier Diversity. International Journal of Human Resource Management 24 (12): 2321-2338.

Torres, C. A. Q., B. Douthwaite, J. I. R. Velasco, and J. Ashby. 2004. Colombia, Latin America and the spread of local agricultural research committees (CIALS): Extension through farmer research. In eds W. Rivera, and G. Alex. Demand-driven approaches to agriculture extension, 10-16. Washington, DC: The World Bank.

Utterback, J.M. 1975. The role of applied research institutes in the transfer of technology in Latin America. World Development 3 (9): 665-673.

Van de Ven A. 2007. Engaged Scholarship. Oxford: Oxford University Press. 
Van Dijk, M.P., and A. Sverisson. 2003. Enterprise clusters in developing countries: mechanisms of transition and stagnation. Entrepreneurship and Regional Development 15: 183-206.

Vorontas, N. 2002. Building competitive firms: technology policy initiatives in Latin America. Technology in Society 24 (4): 433-459.

Wellbrock, W., and Roep, D. 2014. The learning rural area framework: A heuristic tool to investigate institutional arrangements which support collaboration in rural areas, Sociologia Ruralis, June, DOI: 10.1111/soru.12049.

Wenger, E. 1998. Learning, meaning and identity. New York: Cambridge University Press.

Wenger, E. 2000. Communities of practice and social learning systems. Organization 7 (2): 225 $-246$.

Wenger, E., R. McDermott, and W.M. Snyder. 2002. Cultivating communities of practice. Boston, MA: Harvard Business School Press.

Williams, R., R. Slack, and J. Stewart. 2005. Social Learning in Technological Innovation Experimenting with Information and Communication Technologies. Cheltenham: Edward Elgar.

Velluzzi, N.D. 2010. Community Colleges, clusters and competition: A case from Washington wine country. Regional Studies 17 (2): 201-214.

Yin, R. K. 2003. Case study research: Design and methods, Newbury Park, CA: Sage. 
Table 1. Fish Farmers - Technology Adopters and Resultant Benefits

\begin{tabular}{|l|l|l|l|l|l|}
\hline $\begin{array}{l}\text { Technology } \\
\text { Type }\end{array}$ & $\begin{array}{l}\text { Number of } \\
\text { fish farmers } \\
\text { that adopted } \\
\text { technologies } \\
\text { on offer }\end{array}$ & $\begin{array}{l}\text { Number of } \\
\text { adopters that } \\
\text { entered new } \\
\text { markers/ } \\
\text { supply chains } \\
\text { as a result of } \\
\text { adopting these } \\
\text { technologies }\end{array}$ & $\begin{array}{l}\text { Number } \\
\text { of } \\
\text { adopters } \\
\text { achieving } \\
\text { at least } \\
10 \% \text { cost } \\
\text { savings }\end{array}$ & $\begin{array}{l}\text { Number adopters } \\
\text { achieving a } \\
\text { substantial } \\
\text { increase in quality } \\
\text { (by main buyer } \\
\text { standards) }\end{array}$ & $\begin{array}{l}\text { Number } \\
\text { adopters } \\
\text { achieving at } \\
\text { least 10\% } \\
\text { increase in } \\
\text { productivity }\end{array}$ \\
\hline Sand Trap & 32 & 32 & 25 & 32 & 26 \\
\hline $\begin{array}{l}\text { Centre for } \\
\text { Gutting } \\
\text { (shared by the } \\
\text { network) }\end{array}$ & 44 & 44 & 44 & 44 & 44 \\
\hline $\begin{array}{l}\text { Environment } \\
\text { Management } \\
\text { Systems }\end{array}$ & 37 & 37 & 30 & 37 & 42 \\
\hline $\begin{array}{l}\text { Fish Tank } \\
\text { System }\end{array}$ & 15 & 15 & 15 & 12 & 15 \\
\hline
\end{tabular}


Illustration 1. Constituent Elements of the Three Key Intermediation Functions

\section{Brokering}

Nurturing a Coalition Community of Practice - Focal Points:

- Steering Group: Membership structure

- Boundary Events: Steering group meetings

- Boundary Objects: Agenda, strategic/tactical plans and assessment frameworks

- Brokers: Intermediary advisors

Stakeholders involved in Technology Diffusion:

Development of communal identity and meaning shapes the intervention mode

\section{Facilitating \& Configuring}

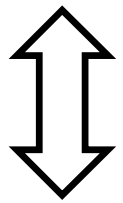

Nurturing a Community of Practice of Networked Agribusiness owners - Focal

Points:

- Boundary Events: Workshops and training \& assistance visits

- Boundary Objects: Translated new technology

- Brokers/Facilitators: Intermediary advisors and trade association officials

Technology recipients:

Development of communal identity and meaning as technology adopters/adapters

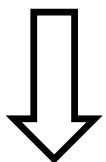

Supportive communal identity, meaning and competences enable the domestication and innofusion of technology amongst agribusiness owners 